\title{
Opportunities and Barriers to the Development of Agriculture 4.0 in the Context of Low Carbon Agriculture in Poland
}

\author{
Arkadiusz PIWOWAR \\ Wrocław University of Economics, Wrocław, Poland \\ arkadiusz.piwowar@ue.wroc.pl
}

\begin{abstract}
Agriculture 4.0, as a vision of agricultural development, has great potential for limiting undesirable and harmful pollution of the natural environment resulting from agricultural activity. The multidimensional and cumulative nature of negative phenomena, mainly related to the chemization of agriculture, raises challenges, related to, among others, to the development of information and communication technologies. The aim of this paper is to provide knowledge about Agriculture 4.0 in Poland, including current opportunities and barriers to its development. The background for the presented issues is the development of a low carbon economy. In Poland, there are Information and communication technologies as well as robotics available, which can provide the basis for solving ecological problems in agricultural production. However, according to analyses, farmers constitute the largest social group in Poland without access to computers and the Internet.
\end{abstract}

Keywords: Agriculture 4.0, Precision Agriculture, ICT, Pesticides, Poland

\section{Introduction}

Contemporary agriculture in order to consciously and deliberately control the biological processes of plants and animals, taking into account the issues of environmental protection, requires much greater knowledge of farmers than it used to do a dozen or so years ago. Agricultural producers operate in an increasingly complex, competitive economic realm and must have knowledge not only in technology and production techniques in agriculture, but also in such fields as economics, law and ecology [20]. In this context, computerization of production and management processes in agriculture is more and more often indicated as a future direction of change. The concept of digital transformation of agriculture is defined in the literature of the subject and the development programs of many institutions and organizations (e.g. European Agricultural Machinery) as Agriculture 4.0 [8]. Similarly to the concept of Industry 4.0, the transformation process in Agriculture 4.0 aimed at increasing competitiveness is also implemented through the use of modern information technology [18]. 


\section{Methods and sources of materials}

The main objective of the work is to provide knowledge about modern trends related to Agriculture 4.0 in Poland, including current opportunities and barriers to its development. These issues were discussed in the context of the development of low carbon agriculture in Poland on the example of plant protection activities. The article presents statistics on the use of information and communication technologies in rural areas in Poland. The literature analysis of the subject was used to identify the status and technical capabilities of ICT in the subject matter studied.

\section{Opportunities of using information and communication technologies in plant protection}

As it was mentioned above, modern information technologies are used in all sectors of the economy. In agriculture, information technologies have been used in both plant and animal production. As Mueller et al. point out, nowadays it is not difficult to indicate possible applications of ICT in agriculture [16]. Information technologies provide users with the tools by which they can acquire, select, analyse, process, and even manage information (Figure 1).

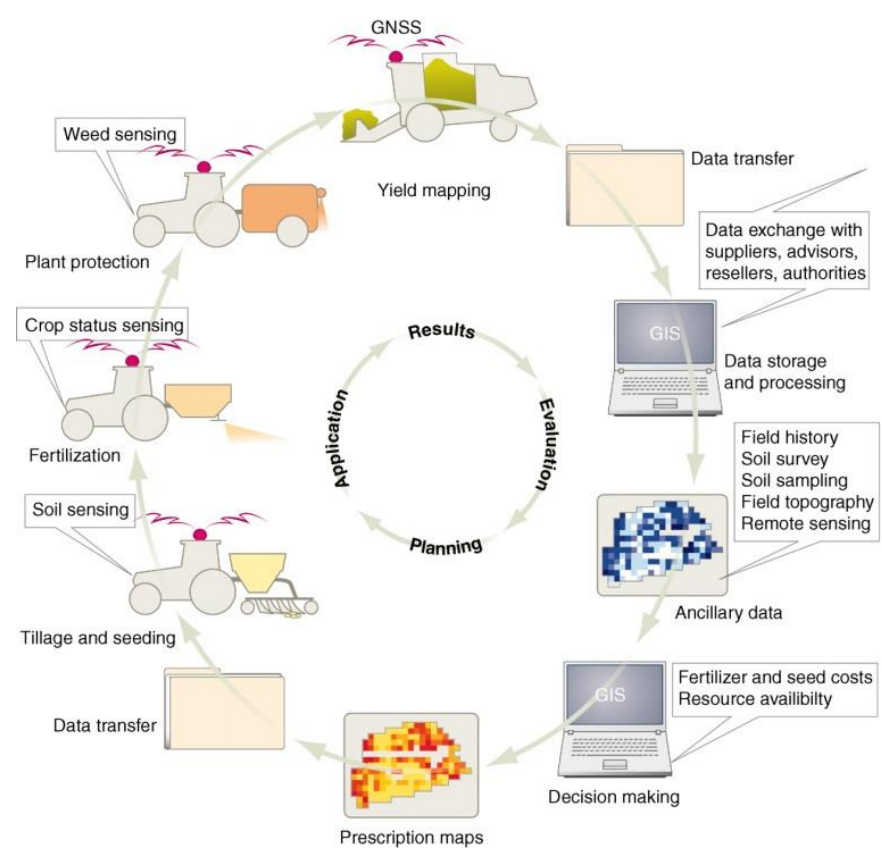

Fig. 1. Precision agriculture information flow in crop production [5].

Agricultural producers have the opportunity to use modern decision-making tools, including those regarding fertilization, plant protection and livestock feed. A number 
of examples of advanced information technology used in agriculture can be found in precision agriculture. Thanks to information and communication technologies, a farmer can acquire and expand knowledge, make contacts with other producers, promote his products and services, order necessary means of production, and handle official affairs [6].

Significant, from the point of view of the subject of this paper, is the use of ICT in the aspect of low-carbon agriculture, i.e. high-yielding agricultural practices that maximally limit threats for natural environment [19]. It is acknowledged that the use of digital techniques is one of the most effective and necessary approaches to the implementation of resource efficient and low carbon agriculture [23]. Innovative ICT solutions enable the most current data to be used in real-time and tailored to the needs of the user [4].

On farms, decision-making processes in the field of chemical plant protection in Poland are often supported by tools in the form of computer systems and applications. In the most elaborate form, these are decision support systems (DSS), i.e. information systems for collecting, processing and providing information to the end user in order to facilitate accurate decision making [21]. A plant health decision support system is a set of procedures and instructions to help a farmer (or an adviser) make the right decision to protect the plantation (Figure 2). There are separate systems for individual pests/crops. For example, one of the best known systems supporting decision-making in potato protection against $P$. infestans in Poland is NegFry [13].

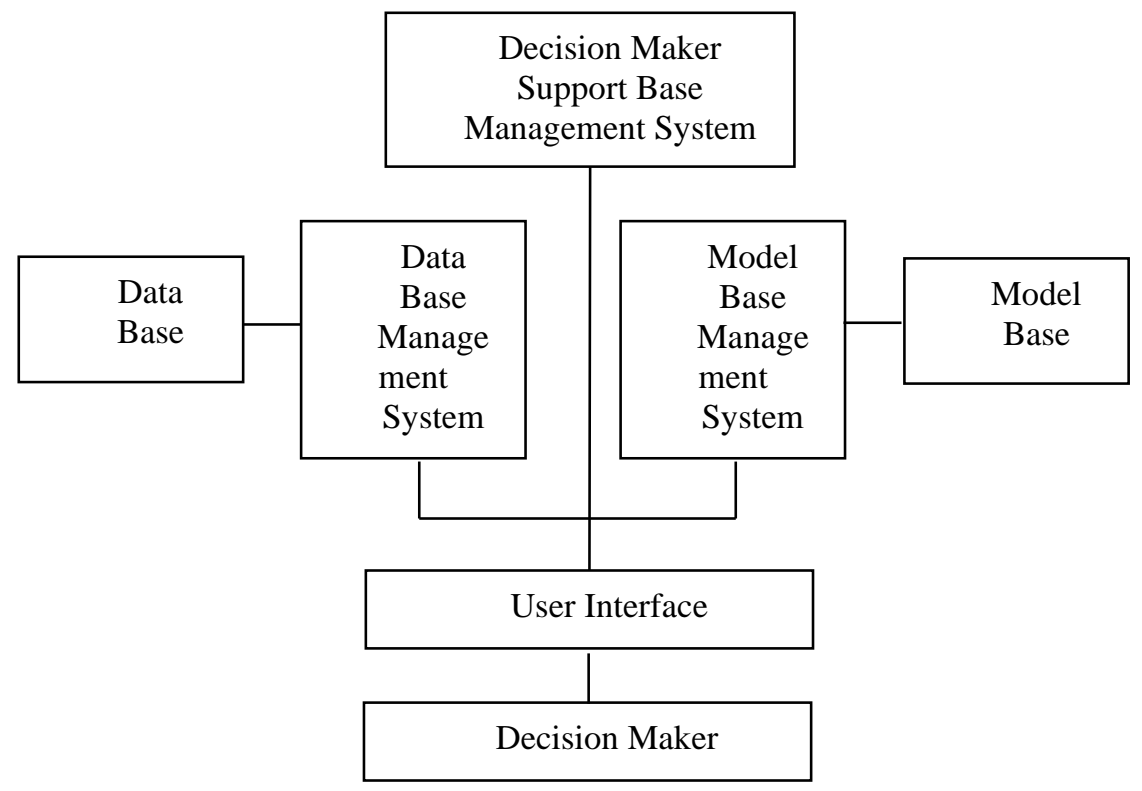

Fig. 2. Typical Decision Support System [12]. 
A typical decision support system comprises from the following elements:

- The Database and the Database Management System;

- The Model Base and the Model Base Management System (MBMS);

- The Dialog Generation and Management System [12].

It is worth emphasizing that the development of decision support systems is also one of the tools to facilitate the implementation of the principles of integrated crop protection. The first works on the development of the "Internet Decision Support System for Integrated Plant Protection" were launched in Poland in 2001. The work was carried out in collaboration with the Danish Institute of Agricultural Sciences, which provided prototypes of disease models [17]. Currently, under mandatory since January 1, 2014 introduction of integrated plant protection system in Poland, state institutions provide farmers with access to information and monitoring of harmful organisms and making appropriate decisions regarding the use of plant protection products. The Plant Protection Institute conducts signalling of pests' occurrence (access via the website http://www.agrofagi.com.pl/). The farmer, on the basis of the descriptions of morphology, biology and control of pests, which are available on the Institute's website, can independently determine the threat to his crops and make an appropriate decision regarding plant protection. The Main Inspectorate of Plant Health and Seed Inspection (www.piorin.gov.pl) also operates an online signalling system based on short-term prognoses of disease and pest development. It provides assistance to the farmer in deciding about the need for plant protection.

Agricultural producers in Poland have also increasingly wide choice of computer software to support farm management. Professional handling of a farm with plant production may be supported with such programmes as AgroNet, Agridata, Elmid, Agronom i FarmWork. Advanced programs enable GPS monitoring with data analysis, route, location and speed recording, planning of services and farming treatments. On Polish market there are also available numerous computer programs to support the management of animal production in farms. The use of these types of programs can greatly help to keep the farm running while simultaneously contributing to its faster development, optimizing production costs while reducing excessive pollution of the natural environment.

In recent years, the market of mobile applications, aimed at facilitating pest control in agricultural, vegetable and fruit crops, is also dynamically developing in Poland, An example of this type of application is "e-pole". In the application you can read the description of plant protection products, the list of diseases, weeds and pests controlled, the recommendations on doses and crop rotation. It is also possible to read the label of each product. The application is available for Android, iOS and Windows. There are also applications available for amateur and hobbyist plant growing, such as the "Doktor Kwiatek" application (Figure 3). 

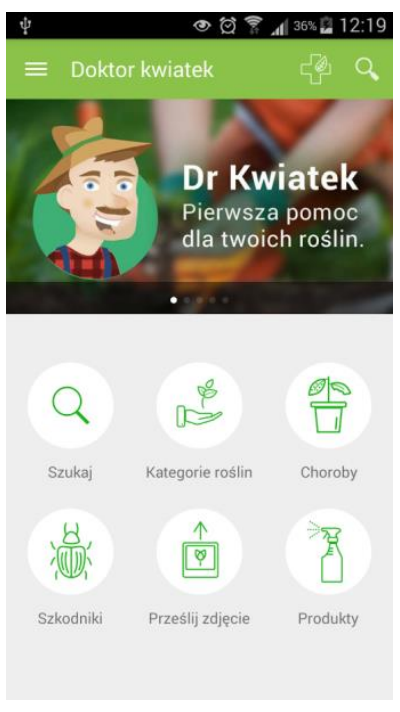

Fig. 3. Dr Kwiatek - Android Apps on Google Play (screenshot) [7].

The "Doktor Kwiatek" application contains an illustrated database of the most common diseases and plant pests. With the application, there is an option to consult the advisor (by taking a photo of the problem with a description and sending it to the Plant ER). The application contains the most important information about plant protection products such as: product names, their purpose or preharvest interval. The application may be downloaded at no additional cost and its proper functioning requires only a smartphone with Android 4.0 or its higher versions.

In the context of Agriculture 4.0, in addition to systems, programs and applications, an important issue are modern methods and techniques of data collection. Currently, there is a real revolution taking place in the way information about crops for precision farming is obtained from the air, mainly due to small, relatively inexpensive unmanned aerial vehicles - drones with mounted multispectral cameras [15]. Obviously, in this case, it is also necessary to use appropriate software for proper interpretation. Drones can also be potentially used as robots to perform protective procedures. Undoubtedly, the advantages of using drones as agricultural machines include the lack of influence on the soil structure (e.g. soil compacting in the case of traditional terrestrial treatments) and the possibility of reaching places inaccessible for field sprayers $[1,9]$.

\section{Current status and barriers of use of Agriculture 4.0 in Poland}

In literature, there is no comprehensive study on the availability and the use of ICT in Polish agriculture. There are fragmentary studies, and their conclusions often point 
out that computer techniques are rapidly entering the farms in Poland, although their use is still relatively low. The results of empirical research obtained by other authors show that a small number of farmers in Poland use specialized computer programs on their farms [2,11].

The development of ICTs in rural areas is linked to many conditions - both technological (computer access, internet, etc.) as well as economic and sociodemographic ones. In Poland, the residents of rural areas are still listed among the social groups most vulnerable to digital exclusion [10], although access to modern information media has become much better in recent years. The analyses on the use of information and communication technologies in rural areas and on farms in Poland are presented in tables 1 and 2 and figures 4 and 5 .

In $2016,80.1 \%$ of Poles had access to a computer, and in rural areas - $77 \%$ (Table 1). Significant improvements have been noted given the time range of the study. In $2016,60.5 \%$ of the population of rural areas in Poland regularly used computers, i.e. by 13.2 percentage points more than in 2010 .

Table 1. Table captions should be placed above the tables [22].

\begin{tabular}{|c|c|c|c|c|c|c|c|c|}
\hline \multicolumn{2}{|l|}{ Specification } & \multirow{2}{*}{$\begin{array}{r}2010 \\
63.7\end{array}$} & \multirow{2}{*}{$\begin{array}{l}2011 \\
67.1\end{array}$} & \multirow{2}{*}{$\begin{array}{l}2012 \\
69.4\end{array}$} & \multirow{2}{*}{$\begin{array}{r}2013 \\
{[\%]} \\
71.7\end{array}$} & \multirow{2}{*}{$\begin{array}{r}2014 \\
73.6\end{array}$} & \multirow{2}{*}{$\begin{array}{l}2015 \\
75.0\end{array}$} & \multirow{2}{*}{$\begin{array}{r}2016 \\
77.0\end{array}$} \\
\hline $\begin{array}{l}\text { Households } \\
\text { posessing a }\end{array}$ & $\begin{array}{l}\text { rural } \\
\text { areas }\end{array}$ & & & & & & & \\
\hline computer & total & 69.0 & 71.3 & 73.4 & 74.7 & 77.1 & 77.9 & 80.1 \\
\hline \multirow[t]{2}{*}{$\begin{array}{l}\text { Regular } \\
\text { computer users }\end{array}$} & $\begin{array}{l}\text { rural } \\
\text { areas }\end{array}$ & 47.3 & 49.8 & 50.2 & 51.4 & 54.8 & 56.0 & 60.5 \\
\hline & total & 57.7 & 60.0 & 60.2 & 60.8 & 63.5 & 64.8 & 69.1 \\
\hline \multirow[t]{2}{*}{$\begin{array}{l}\text { Households with } \\
\text { Internet access }\end{array}$} & $\begin{array}{l}\text { rural } \\
\text { areas }\end{array}$ & 56.2 & 61.2 & 66.1 & 67.8 & 71.5 & 72.0 & 77.8 \\
\hline & total & 63.4 & 66.6 & 70.5 & 71.9 & 74.8 & 75.8 & 80.4 \\
\hline $\begin{array}{l}\text { Households with } \\
\text { broadband }\end{array}$ & $\begin{array}{l}\text { rural } \\
\text { areas }\end{array}$ & 46.9 & 53.4 & 60.5 & 63.0 & 66.7 & 64.7 & 71.3 \\
\hline Internet access & total & 56.8 & 61.1 & 67.0 & 68.8 & 71.1 & 71.0 & 75.7 \\
\hline
\end{tabular}

Farmers in Poland are reluctant to use cloud computing services - disk space on the Internet (Figure 4). 


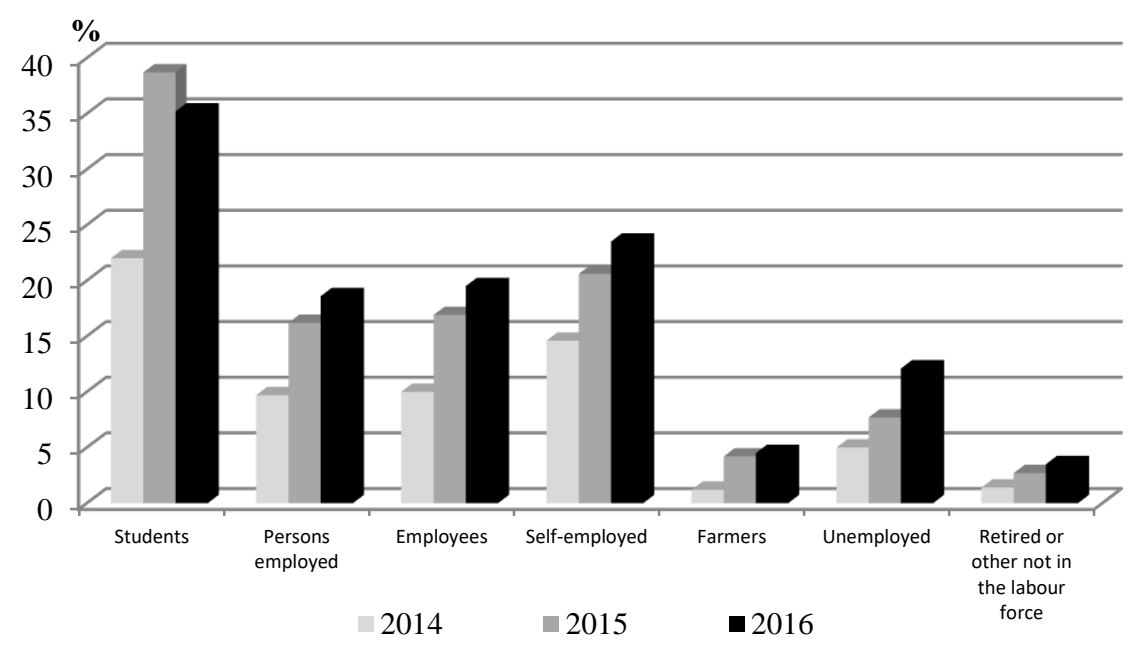

Fig. 4. Individuals who use cloud computing services to store files [22].

In 2016, Poland recorded a significant variation in the use of storage space on the Internet for file saving, taking into account the type of professional activity of the users. Cloud services were used by $35.2 \%$ of students, compared to $4.5 \%$ of farmers and $3.5 \%$ of retired and professionally inactive people. In each of the groups in terms of professional activity, an increase in the examined indicator was noted in the years 2014-2016.

As mentioned earlier, more and more useful information technology programs for farmers are available in the mobile version. The percentage of people using and not using mobile devices to connect to the Internet in 2016, regarding the type of professional activity, is shown in Table 2.

Table 2. Individuals using and not using mobile devices to access the Internet in 2016 [22].

\begin{tabular}{lcc}
\hline Specification & $\begin{array}{c}\text { Individuals using mobile } \\
\text { devices }\end{array}$ & $\begin{array}{c}\text { Individuals not using } \\
\text { mobile devices }\end{array}$ \\
\hline [\%] & \\
\hline Students & 83.4 & 15.4 \\
Persons employed & 34.9 & 50.1 \\
Employees & 37.2 & 50.5 \\
Self-employed & 39.0 & 50.1 \\
Farmers & 10.4 & 46.3 \\
Unemployed & 26.6 & 42.3 \\
$\begin{array}{l}\text { Retired or other not in } \\
\text { the labour force }\end{array}$ & 8.9 & 31.6 \\
\hline
\end{tabular}


Agricultural producers in Poland are a professional group that makes little use of portable devices. A detailed analysis of the data showed that for the purpose of Internet connecting outside home and place of work, in 2016 farmers more frequently used mobile phones or smartphones rather than portable computers, such as laptops and tablets (Figure 5).

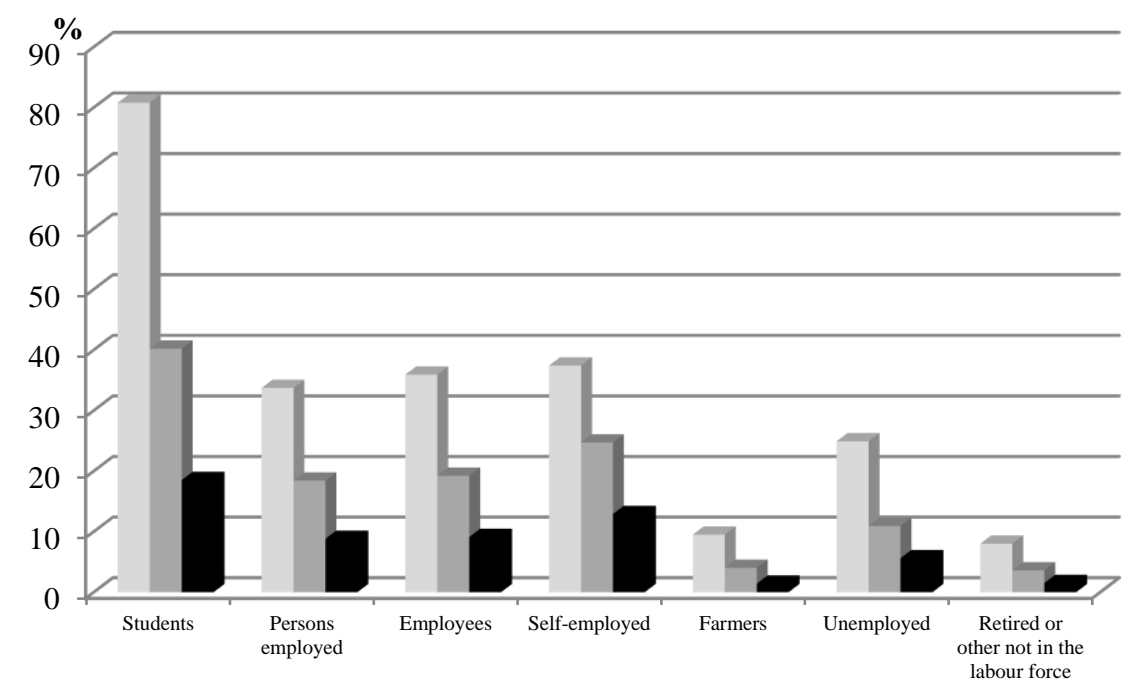

Mobile phone or smartphone $\square$ Portable computer (e.g. laptop,netbook) $\square$ Tablet

Fig. 5. Individuals using mobile devices to access the Internet by types of device in 2016 [22].

Access to modern ICT tools in agriculture is an important element in determining the proper and efficient operation of farms in the ecological sense. In this context, the results of research on the use of mobile devices for connecting to the Internet by farmers against other professional activities are not optimistic.

It is also worth mentioning about another factor limiting the use of ICT in Polish agriculture. Based on the research conducted by Borusewicz et al. [2] the relationship between farm size, the education and the age of respondents and the development of precision agriculture may be noted. Precision farming technology is better known among farmers up to the age of 40 who have higher education and large farms. The level of use of information and communication technologies is also significantly related to the level of development of the commune [14].

\section{Conclusion}

Information and communication technologies are a very important element, the use of which may be important in agricultural holdings from the point of view of developing low carbon agriculture. Teleinformatic techniques, geolocation systems, sensors, etc. allow for the application of varied doses of fertilizers, plant protection agents, seeds 
and other means of production, resulting from locally varied needs. This limits not only economic losses, but also a potential threat to the natural environment. Agriculture 4.0 can lead to faster and more flexible solutions for the organization of plant and animal production while limiting chemization of agriculture.

According to the information presented in this paper, agricultural producers in Poland have access to technologically advanced systems, programs and applications in the field of plant protection. By using information and communication technology, a farmer can gain and broaden his knowledge of this field, which should result in optimal decisions in given organizational and natural conditions. In Poland, despite improvements in recent years, there is still a problem of access to computers and the Internet in rural areas. Two basic prerequisites must be fulfilled for ICT to be used: universal access to ICT devices and appropriate skills to use then (knowledge and competence). There is also a problem of low degree of integrity of available databases and information systems in the field of plant health in Poland.

Acknowledgements. This study was conducted and financed in the framework of the research project "The state and prospects of the development of low-carbon agriculture in Poland and the behaviour of agricultural producers", granted by the National Science Centre in Poland, program SONATA, grant No. 2016/21/D/HS4/00087.

\section{References}

1. Berner, B., Chojnacki, J.: Zastosowanie bezzałogowych statków powietrznych do opryskiwania upraw rolniczych. Technika Rolnicza. Ogrodnicza. Leśna 2, 23-25 (2017).

2. Borusiewicza, A., Kapela, K., Drożyner, P., Marczuk, T.: Application of precision agriculture technology in Podlaskie voivodeship. Agricultural Engineering 20(1), 5-11 (2016).

3. Borusiewicza, A.., Kapela, K., Gugała, M.: The use of it technologies in farms on the example of Zambrów and Wysokie mazowieckie county. Agricultural Engineering 20(3), 27-34 (2016).

4. Deichmann, U., Goyal, A., Mishra, D.: Will Digital Technologies Transform Agriculture in Developing Countries? Agricultural Economics 47(S1), 21-33 (2016).

5. Gebbers, R., Adamchuk, V. I.: Precision Agriculture and Food Security, Science 327 (5967), 828-831 (2010).

6. Heilig, G.: Information society and the countryside: can internet-based system bring income alternatives to rural areas? In: J. Bański, J. Owsiński (eds.), Alternatives for European Rural Areas, Rural Areas and Development, pp. 65-79. ERDN, Warsaw (2003).

7. Home-Dr Kwiatek, https://play.google.com/store/apps/details?id=target.com.pl, last accessed 2017/08/31.

8. Home-SMART FARMING, http://cema-agri.org/page/what-agriculture-40, last accessed 2017/09/04.

9. Huang, Y., Hoffmann, W. C., Lan, Y., Wu, W., Fritz, B. K.: Development of a Spray System for an Unmanned Aerial Vehicle Platform. Applied Engineering in Agriculture 25(6), 803-809 (2009). 
10. Jaska, E.: Dostępność i wykorzystanie technologii informacyjno-komunikacyjnych na obszarach wiejskich. Roczniki Naukowe SERiA XVII(4), 110-115 (2015).

11. Kocira, S., Lorencowicz, E.: Wykorzystanie technik komputerowych w gospodarstwach rodzinnych. Inżynieria Rolnicza 6(131), 7-83 (2011).

12. Manos, B. D., Papathanasiou, J., Bournaris, T., Voudouris, K.: A DSS for sustainable development and environmental protection of agricultural regions. Environmental Monitoring and Assessment 164(1-4), 43-52 (2010).

13. Matysek, K.: Systemy wspierające podejmowanie decyzji w ochronie upraw ziemniaka przed zarazą. Ziemniak Polski 2, 46-50 (2014).

14. Mazur, M.: Poziom rozwoju społeczno-gospodarczego obszarów wiejskich a wykorzystanie technologii-informacyjno-komunikacyjnych (TiK) w rolnictwie województwa mazowieckiego. Acta Sci. Pol., Administratio Locorum 11(3), 201-214 (2012).

15. Mazur, P., Chojnacki, J.: Wykorzystanie dronów do teledetekcji multispektralnej w rolnictwie precyzyjnym. Technika Rolnicza. Ogrodnicza. Leśna 1, 25-28 (2017).

16. Mueller, W., Joachimiak, H., Weres, J.: Systemy informatyczne sektora rolniczego bazujące na technologii .NET 2005 I SQL SERVER 2005. Journal of Research and Applications in Agricultural Engineering 53(1), 32-34 (2008).

17. Nieróbca, A., Zaliwski, A. S.: Rozwój internetowego systemu wspomagania decyzji w ochronie zbóż. Inżynieria Rolnicza 7(125), 167-173 (2010).

18. Ozdogan, B., Gacar, A., Aktas, H.: Digital agriculture practices in the context of Agriculture 4.0. Journal of Economics, Finance and Accounting 4(2), 184-191 (2017).

19. Piwowar, A.: Ekoinnowacje w zakresie agrochemikaliów i ich wpływ na rozwój niskoemisyjnej gospodarki. Przemysł Chemiczny 96(8), 1625-1627 (2017).

20. Piwowar, A.: Zastosowanie technologii informacyjno-komunikacyjnych $\mathrm{w}$ doradztwie rolniczym. Zagadnienia Doradztwa Rolniczego 4, 112-119 (2013).

21. Rączka, K., Kowalski, M., Gąsiorek, S.: Systemy wspomagające podejmowanie decyzji w przedsiębiorstwie. Inżynieria Rolnicza 6(94), 205-212 (2007).

22. Społeczeństwo informacyjne w Polsce: Wyniki badań statystycznych z lat 2012-2016, https://stat.gov.pl/files/gfx/portalinformacyjny/pl/defaultaktualnosci/5497/1/10/1/spolecze nstwo_informacyjne_w_polsce_2012-2016.pdf, last accessed 2017/09/10.

23. Yane, D.: Research and Analysis about System of Digital Agriculture Based on a Network Platform. In: Li D., Liu Y., Chen Y. (eds.) Computer and Computing Technologies in Agriculture IV. CCTA 2010. IFIP Advances in Information and Communication Technology, vol. 345, pp. 274-282, Springer, Berlin, Heidelberg (2011). 